\title{
MAKALAH
}

\section{Rencana Usaha}

\author{
Oleh \\ Moh Faizin Lahay
}

1121416016

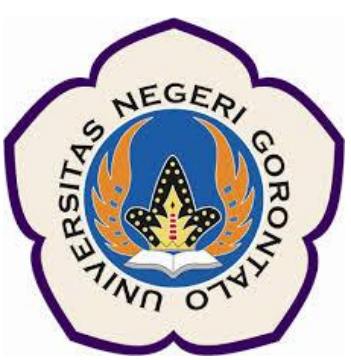

JURUSAN TEKNOLOGI HASIL PERIKANAN

FAKULTAS PERIKANAN DAN ILMU KELAUTAN

UNIVERSITAS NEGERI GORONTALO 


\section{KATA PENGANTAR}

Dengan menyebut nama Allah SWT yang Maha Pengasih lagi Maha Panyayang, Kami panjatkan puja dan puji syukur atas kehadirat-Nya, yang telah melimpahkan rahmat, hidayah, dan inayah-Nya kepada kami, sehingga kami dapat menyelesaikan makalah yang berjudul "Rencana Usaha".

Akhir kata, kami menyadari sepenuhnya bahwa masih ada kekurangan baik dari segi susunan kalimat maupun tata bahasanya. Oleh karena itu dengan tangan terbuka kami menerima segala saran dan kritik dari pembaca agar kami dapat memperbaiki makalah ini. 
DAFTAR ISI

KATA PENGANTAR

DAFTAR ISI.

BAB.I PENDAHULUAN.

A.

Latar

Belakang

Masalah.

Rumusan

B.

Tujuan

C.

Penulisan

D.

Manfaat

Penulisan

BAB.II PEMBAHASAN

1. Pengertian dari profil usaha atau bisnis

2.

Fungsi-fungsi usaha atau

bisnis.

3. Ruang lingkup usaha atau bisnis secara umum

4.

Bentuk dasar kepemilikan usaha atau

bisnis.

5

bisnis.....

Tujuan dari usaha atau

6.

Konsep tentang ekonomi usaha atau

bisnis

7.

Bisnis yang bagaimana yang sesuai dengan

syariah.

$8 . \quad$ Jenis usaha atau

bisnis

9.

Kategori-kategori usaha atau

bisnis.

10. Teknik mengembangkan usaha atau bisnis

BAB.III PENUTUP.

DAFTAR PUSTAKA 


\section{BAB I \\ PENDAHULUAN}

\section{A. Latar Belakang Masalah}

Dalam mempertahankan hidupnya manusia diberi kebebasan dalam memenuhi kebutuhan-kebutuhannya. Kita pernah mendengar berita tentang suatu perusahaan dengan produknya yang berhasil menguasai pasar dan mampu mengeruk keuntungan yang besar dari hasil penjualan produknya. Atau suatu perusahaan yang meluncurkan suatu produk baru dan memperoleh keuntungan bisnis besar. Atau mungkin justru sebaliknya, yang menyatakan kebangkrutan suatu bisnis karena tidak mampu bersaing di pasar atau karena produknya tidak diminati oleh pasar. Pemberlakuan peraturan perundang-undangan baru yang akhirnya dapat menimbulkan turunnya daya beli masyarakat juga dapat menyebabkan lesunya suatu bisnis.

Keberhasilan dan kegagalan seperti uraian di atas merupakan kenyataan yang dapat dialami oleh suatu usaha. Dunia usaha berisi dengan persaingan, peluang, tantangan, kegairahan maupun kelesuan yang dapat menyebabkan naik turunnya suatu usaha.

Usaha atau bisnis yang dirintis dari awal hingga menuju kesuksesan dalam diri pribadi seseorang dilakukan dengan hati yang sabar.

B. Rumusan Masalah.

1. Apakah pengertian dari profil usaha atau bisnis?

2. Apakah fungsi-fungsi usaha atau bisnis?

3. Apakah ruang lingkup usaha atau bisnis secara umum?

4. Bagaimana bentuk dasar kepemilikan usaha atau bisnis?

5. Apakah tujuan dari usaha atau bisnis? 
6. Bagaimanakah konsep tentang ekonomi usaha atau bisnis?

7. Bisnis yang bagaimana yang sesuai dengan syariah?

C. Tujuan Penulisan.

1. Untuk memberikan pemahaman tentang pengertian dari profil usaha atau bisnis?

2. Untuk mengetahui fungsi-fungsi usaha atau bisnis?

3. Untuk menjelaskan ruang lingkup usaha atau bisnis secara umum?

4. Untuk menggambarkan bentuk dasar kepemilikan usaha atau bisnis?

5. Untuk mengetahui tujuan dari usaha atau bisnis?

6. Untuk menjelaskan Bagaimana konsep tentang ekonomi usaha atau bisnis?

7. Untuk menjabarkan Bisnis yang bagaimana yang sesuai dengan syariah?

\section{Manfaat Penulisan.}

1. Manfaat Akademis.

Sebagai referensi dan bahan tambahan untuk memberikan informasi kepada Para pengusaha maupun lainnya tentang Profil usaha dan dapat melatih kreativitas yang dimiliki setiap mahasiswa dalam menulis sebuah makalah.

\section{Manfaat Praktis.}

Bagi pihak internal ( pihak pengusaha / wirausaha) sebagai salah satu alat ukur untuk mengetahui tentang profil usaha sedangkan bagi pihak eksternal ( umum) memberikan gambaran tentang profil usaha.

\section{E. Metode Penulisan.}

Studi Kepustakaan yaitu pengumpulan data dilakukan dengan cara mencari , membaca, dan mempelajari referensi buku-buku, situs internet serta catatan kuliah yang berhubungan dengan objek penulisan makalah sebagai subjek atau bahan dalam pembuatan penulisan makalah ini . 


\section{BAB II \\ PEMBAHASAN}

\section{Pengertian Profil Usaha dan Bisnis}

Untuk memahami tentang Profil usaha atau bisnis, pertama kita harus mengetahui apa yang di maksud dengan profil dan bisnis. Profil adalah Menggambarkan, menjelaskan, mengenalkan yang mencakup suatu objek. Bisnis adalah pertukaran barang, jasa, atau uang yang saling menguntungkan atau memberikan manfaat. (Skinner, 1992). "Bisnis is all those activities in providing the goods and services needed and desired by people." Dalam pengertian ini kegiatan bisnis sebagai aktivitas yang menyediakan barang dan jasa yang diperlukan atau diinginkan oleh konsumen, dapat dilakukan oleh organisasi perusahaan yang memiliki badan hukum, perusahaan yang memiliki badan usaha, maupun perorangan yang tidak memiliki badan hukum maupun badan usaha seperti pedagang kaki lima, warung yang tidak memiliki SITU dan SIUP, serta usaha informal lainnya.Produk yang dihasilkan dan diperdagangkan oleh kegiatan bisnis mencakup keseluruhan tangible goods dan intangible goods.

Pengertian bisnis lainnya diberikan oleh Griffin dan Ebert (1966), "Business is an organization that provides goods or services in order to earn profit." Sejalan dengan definisi tersebut, aktivitas bisnis melalui penyediaan barang dan jasa bertujuan untuk menghasilkan profit/laba. Suatu perusahaan dikatakan menghasilkan laba apabila total penerimaan pada satu periode (total revenues) lebih besar dari total biaya (total costs) pada periode yang sama. Laba merupakan daya tarik utama yang mendorong seseorang untuk melakukan kegiatan bisnis. Melalui laba yang diciptakan oleh aktivitas bisnis, maka pelaku bisnis dapat mengembangkan skala usahanya menjadi lebih besar lagi. Dari pengertian diatas, bisnis dapat diartikan sebagai Suatu Organisasi atau lembaga yang menyediakan 
barang dan/atau jasa yang bertujuan untuk mendapatkan keuntungan (abal). Dengan demikian, faktor pendorong organisasi atau lembaga untuk memulai bisnis dan mengembangkannya adalah prospek mendapatkan keuntungan (laba). Akumulasi laba yang diperoleh melalui aktivitas bisnis dapat pula diinvestasikan ke dalam portofolio usaha yang dapat meningkatkan nilai perusahaan. Dalam kaitannya dengan investasi kembali laba usaha, maka laba usaha dapat diinvestasikan kembali untuk memperbesar skala usaha, pembelian saham, pembelian obligasi, atau diinvestasikan ke dalam usaha prospektif yang kemungkinan akan memberikan kontribusi laba jangka panjang yang lebih besar ke dalam kelompok usaha perusahaan.

Badan usaha sebagai wadah untuk melakukan usaha (bisnis) yang sebagian besar didirikan untuk tujuan mencari keuntungan (profit oriented organization) Memahami ekonomi merupakan merupakan dasar untuk memahami bisnis. Ada beberapa kunci untuk memahami ekonomi, yaitu:

\section{a. Sumber - sumber daya.}

Sumber daya terdiri dari tiga kelompok yaitu: sumber daya alam, kapital, dan tenaga kerja. Sumber daya alam: disediakan oleh alam dalam jumlah terbatas, harus diproses lebih dahulu atau digunakan untuk memproduksi barang dan jasa lainnya. Sumber daya modal (capital produk yang diproduksi untuk tujuan membuat berbagai barang-barang dan jasa. Sumber modal (current assets):

1. Modal jangka pendek, digunakan habis dalam proses produksi

2. Modal jangka panjang (modal tetap / fixed capital), dapat digunakan berulangkali dalam proses produksi sumber daya manusia (tenaga kerja): merupakan kemampuan manusia dari suatu bangsa. Tanpa adanya sumber daya manusia ini tidak mungkin produktif dalam menggunakan baik sumber daya alam maupun sumber daya modal.

\section{b. Barang - Barang dan Jasa.}

Sumber daya digunakan untuk menghasilkan barang - barang dan jasa yang akan digunakan untuk memenuhi kebutuhan dan keinginan manusia.

\section{c. Alokasi Sumber Daya.}

Dapat diketahui bahwa ekonomi menggambarkan adanya fungsi sosial pada masyarakat yang tertuju pada tercapainya kondisi kesejahteraan fisik, yaitu dengan memanfaatkan sumber daya dan fasilitas yang ada pada masyarakat. Bila dikaitkan dengan bisnis dan dunia bisnis maka dunia ekonomi terutama akan berperan dalam menentukan:

1. Budaya ekonomi atau gaya bertindak sebagai manusia ekonomi.

2. Corak ragam sumber daya manusia berkecimpung dalam dunia bisnis berikut pengembangan manusia dan hambatannya.

3. Kondisi teknologi dan manajemen pada umumnya, serta konsistensi dan 
inkonsistensinya dengan laju pembangunan.

\section{Fungsi-fungsi Bisnis}

Fungsi merupakan rangkaian pekerjaan yang dilakukan oleh organisasi tertentu yang dapat dibedakan dengan rangkaian pekerjaan lainnya yang dilakukan oleh organisasi yang berbeda. Fungsi yang dilakukan oleh aktivitas bisnis dapat dikelompokkan ke dalam tiga fungsi dasar, yaitu acquiring raw materials, manufacturingraw materials into products, dandistributing product to consumer.

a. Acquiring raw materials, merupakan fungsi bisnis yang pertama, yaitu memperoleh bahan baku.

b. Manufacturingraw materials into products, merupakan fungsi bisnis yang mengolah suau bahan baku menjadi produk.

c. Distributing product to consumer, merupakan suatu fungsi bisnis yang mendisttribusikan suatu produk dari produsen kepada konsumen.

3. Ruang Lingkup Bisnis.

Menurut Philip Kotler (2001:7) produk yang dipasarkan dalam suatu kegiatan bisnis mencakup 10 entitas produk, yaitu:

a. Informations, media massa baik cetak maupun elektronik merupakan pelak bisnis informasi.

b. Places, kategori places misalnya tempat wisata, tempat tujuan wisata memiliki objek wisata yang dapat dijual kepada para wisatawan baik wisatawan lokal maupun wisatawan mancanegara.

c. Experiences, manusia senang melakukan berbagai aktivitas untuk memperoleh pengalaman-pengalaman tertentu dalam hidupnya. Dengan pengalaman tersebut manusia dapat mencapai kepuasan yang diinginkan sehingga aktivitas yang dilakukan menjadi hal yang dibutuhkan oleh manusia.

d. Organizations, suatu perusahaan menghasilkan produk bermutu dan memuaskan kebutuhan konsumen serta memiliki kinerja keuangan yang baik, menyebabkan perusahaan memiliki nilai yang berbeda dibanding perusahaan yang lain dimata konsumen maupun investor. Apabila perusahaan menghasilkan produk baru, maka produk baru yang dihasilkan perusahaan tersebut pada umumnya akan dinilai memiliki kualitas yang baik oleh konsumen karena konsumen memiliki rujukan pengalaman mengkonsumsi produk- produk perusahaan tersebut sebelumnya.

e. Ideas, seluruh produk yang dipasarkan saat ini pada awalnya berasal dari suatu ide produk. Ide dapat melahirkan inovasi produk yang berkualitas dan mempunyai nilai jual yang baik dipasaran.

f. People, manusia dengan segala kemampuan dan talenta yang dimilikinya dapat menjadi komoditi bisnis.

g. Properties, hak kepemilikan seseorang terhadap benda - benda berharga dapat dijadikan komoditi bisnis. 
h. Events, suatu wahana yang dapat di jual kepada publik dan menjadi bagian dari kegiatan bisnis.

i. Tangible goods, suatu produk berkualitas dan yang memiliki kandungan jasa di dalamnya atau sudah banyak dikenal konsumen serta dapat diperjualbelikan sehingga membentuk aktivitas bisnis.

j. Services, jasa bersifat intangible yang berarti keberadaan jasa tak dapat dilihat secara kasat mata, tetapi bisa dirasakan manfaatnya setelah konsumen mengonsumsi jasa tersebut. Jasa bersifat inseparable, yaitu tak dapat dipisahkan dari si pemberi jasa sehingga kualitas jasa yang akan diperoleh konsumen sangat bergantung pada si pemberi jasa tersebut. Jasa juga memiliki sifat variability, artinya jasa yang diberikan oleh pemberi jasa memiliki variasi antara satu pemberian jasa dengan pemberian jasa yang lainnya meskipun dilakukan pemberi jasa yang sama. Hal ini dipengaruhi oleh suasana psikologis pemberi jasa pada saat melakukan pemberian jasa.

\section{Bentuk Dasar Kepemilikan Bisnis.}

Meskipun bentuk kepemilikan bisnis berbeda-beda pada setiap negara, ada beberapa bentuk yang dianggap umum:

a. Perusahaan perseorangan: bisnis yang kepemilikannya dipegang oleh satu orang. Pemilik perusahaan perseorangan memiliki tanggung jawab tak terbatas atas harta perusahaan. Artinya, apabila bisnis mengalami kerugian, pemilik lah yang harus menanggung seluruh kerugian itu. Hal ini sangat besar keuntungan akan tetapi besar pula resiko yang harus kita dapatkan.

b. Persekutuan: bentuk bisnis dimana dua orang atau lebih bekerja sama mengoperasikan perusahaan untuk mendapatkan profit. Sama seperti perusahaan perseorangan, setiap sekutu (anggota persekutuan) memiliki tanggung jawab tak terbatas atas harta perusahaan. Persekutuan dapat dikelompokkan menjadi persekutuan komanditer dan firma.

c. Perseroan: bisnis yang kepemilikannya dipegang oleh beberapa orang dan diawasi olehdewan direktur. Setiap pemilik memiliki tanggung jawab yang terbatas atas hartaperusahaan.

d. Koperasi: adalah bisnis yang beranggotakan orang-orang atau badan hukum koperasi dengan melandaskan kegiatannya berdasarkan prinsip koperasi sekaligus sebagai gerakan ekonomi rakyat yang berdasarkan asas kekeluargaan. Koperasi bertujuan untuk menyejahterakan anggotanya. Karateristik utama koperasi yang membedakan dengan badan usaha lain adalah anggota koperasi memiliki identitas ganda. Identitas ganda maksudnya anggota koperasi merupakan pemilik sekaligus pengguna jasa koperasi.

\section{Tujuan Bisnis.}

Business actor melakukan aktivitas bisnis untuk mencapai berbagai tujuan.

"Objectivitas are needed in every area where performance and results directly 
and vitally affect the survival and prosperity of the business" (Tujuan dibutuhkan di setiap area dimana kinerja dan hasil secara langsung dan menentukan akan memengaruhi kelangsungan hidup dan kemakmuran perusahaan).

Bertitik tolak pada usaha pencapaian tujuan-tujuan tersebut, maka tentunya proses pencapaian tujuan bisnis melalui pengelolaan sumber daya ekonomi secara optimal harus dilakukan dengan memperhatikan kepentingan dan kemanfaatan bagi para pemilik sumber daya ekonomi atau pemilik faktor-faktor produksi dan masyarakat pada umumnya.

Tercapainya tujuan bisnis akan bersifat langgeng (lebih bersifat jangka panjang) kalau didukung secara inclusif tercapainya tujuan para pihak yang terlibat dalam kegiatan bisnis tersebut. Misalnya pihak tenaga kerja, supplier bahan, pemilik modal dan pihak-pihak eksternal lainnya. Dengan demikian, etika bisnis meliputi keseluruhan proses manajemen perusahaan mengenai pengelolaan sumber daya ekonomi di mana para pemilik sumber daya ekonomi ini sama-sama memperoleh manfaat secara ekonomi yan layak. Di samping itu, masyarakat mendapatkan manfaat sosial yang positif dengan adanya pemberdayaan sumber daya ekonomi tersebut. Bagi para pemilik sumber daya ekonomi tentunya manfaat tersebut diukur dengan ukuran ekonomi dan sosial yang layak.

Tujuan perusahaan merupakan cerminan dari berbagai hasil yang diharapkan bisa dilakukan oleh bagian-bagian organisasi/ aktivitas fungsional perusahaan (produksi, pemasaran, personalia, dll) yang akan menentukan kinerja perusahaan dalam jangka panjang. Key result area suatu perusahaan mencakup market standing, innovation, physical and financial resources, profitability, manager performance and development, worker performance and attitude, public responbility.

a. Market Standing.

Penguasaan pasar atau market standing merupakan salah satu tujuan utama perusahaan. Penguasaan pasar akan memberikan jaminan bagi perusahaan untuk memperoleh pendapatan penjualan (sales revenue) dan profit dalam jangka panjang. Penguasaan pasar tidak hanya di ukur dari besarnya tingkat penjualan yang dapat dilakukan perusahaan(market size), melainkan perusahaan harus mampu membaca potensi pasar dan arah persaingan pada masa yang akan datang melalui penelaahan aktivitas pesaing yang tercermin dari teknologi yang di pasok para supplier kepada perusahaan pesaing, sehinggaproduk perusahaan tidak akan tersisih dari pasar oleh produk saingannya.

b. Innovation.

Menurut Drucker (1969: 90), terdapat dua jenis inovasi pada setiap bisnis. Pertama, inovasi produk atau jasa. Kedua, inovasi berbagai keahlian (skills) dan aktivitas-aktivitas yang diperlukan untuk menghasilkan inovasi jenis pertama tersebut. Lebih lanjut inovasi berkaitan dengan penciptaan nilai (value creation) yang akan memberi konsumen kepuasan lebih besar untuk setiap rupiah yang dia 
belanjakan. Dalam hal ini harus di ingat bahwa konsumen sebagai pembeli bersedia menukar uang yang mereka miliki dengan barang dan jasa, karena barang dan jasa tersebut memiliki nilai (value). Oleh sebab itu, tujuan bisnis yang ingin di capai melalui inovasi adalah menciptakan nilai pada suatu produk. Misalnya, pada saat seorang konsumen membeli jam tangan rolex, maka selain membeli ketepatan waktu, konsumen tersebut juga berharap jam tangan rolex yang dipakai dapat menaikan nilai diri (personal value) konsumen itu sendiri. Demikian pula pada saat konsumen membeli mie instan merk indomie, dia bersedia menukar uangnya karena akan memperoleh kenikmatan mengkonsumsi mie.

c. Physical and Financial Resource.

Bagi perusahaan yang bergerak di bidang manufaktur, kemampuan perusahaan untuk memperoleh suplai bahan baku yang berkelanjutan dengan harga yang bersaing akan sangat menetukan daya saing perusahaan. Selain penguasaan terhadap sumber daya fisik, perusahaan harus memiliki penguasaan sumber daya keuangan yang memadai. Dengan demikian perusahaan apapun jenisnya harus memiliki tujuan penguasaan terhadap sumber daya fisik dan keuangan. Para pelaku bisnis yang memiliki badan usaha seperti Perseroan Terbatas, Persekutuan Komanditer (CV), Firma, Koperasi merupakan contoh badan usaha yang bertujuan menghasilkan laba. Demikian pula kegiatan usaha yang dilakukan perorangan yang tidak memiliki badan usaha, seperti para pedagang kaki lima, warung, kios, dan usaha informal lain memiliki tujuan utama untuk menghasilkan profit. Bisnis yang dilakukan para pelaku bisnis tidak hanya menghandalkan keuntungan/laba sesaat melainkan diharapkan dengan adanya laba, maka perusahaan dapat menumbuh kembangkan usahanya menjadi usaha yang semakin besar dan semakin menguntungkan.

Perusahaan besar seperti Coca Cola, Levis, Unilever mengembangkan suatu budaya perusahaan yang kemudian disebut The Living Company, dimana salah satu ciri dari budaya perusahaan tersebut adalah melakukan penginvestasian kembali sebagian dari keuntungan bisnis perusahaan dalam aktivitas bisnis perusahaan memiliki daya tahan yang tinggi terhadap fluktuasi usaha. Hal ini berbeda dengan perusahaan yang tidak mengembangkan budaya perusahaan The Living Company, dimana keuntungan perusahaan hanya dinikmati oleh pemilik perusahaan dan membiarkan perusahaan dalam kondisi keuangan yang tidak sehat sehingga apabila terjadi resesi atau krisis ekonomi, maka perusahaan tersebut dapat dipastikan akan lebih cepat mengalami tekanan financial yang sering kali berakhir dengan kebangkrutan.

d. Manager Performace and Development.

Manager merupakan orang yang secara operasional bertanggung jawab terhadap pencapaian tujuan organisasi. Untuk dapat mengelola perusahaan yang baik, manager perlu memiliki berbagai kemampuan (skill) dan keahlian (expertise) yang berkaitan dengan profesinya. Dengan demikian, peningkatan kinerja dan 
pengembangan kemampuan manager melalui serangkaian kegiatan kompensasi yang menarik serta program training and development secara berkelanjutan, harus menjadi tujuan dari setiap perusahaan.

e. Worker Performance and Attitude.

Selain manager, sumber daya manusia yang harus memperoleh perhatian besar dari perusahaan adalah para karyawan. Satu hal penting yang harus diketahui oleh perusahaan adalah sikap para karyawan terhadap pekerjaan dan juga perusahaan. Sikap karyawan terkait dengan kondisi kerja dan kompensasi yang diterima oleh karyawan. Karena itu, untuk kepentingan perusahaan jangka panjang, perusahaan harus membuat tujuan yang spesifik berkaitan dengan pemeliharaan dan pengembangan karyawan agar karyawan-karyawan tersebut dapat bekerja dengan baik.

f. Public Responsibility.

Bisnis harus memiliki tanggung jawab sosial, seperti memajukan kesejahteraan masyarakat, mencegah terjadinya polusi, menciptakan lapangan kerja, dan lain-lain. Saat ini perusahaan yang melakukan kegiatan produksi barang dan jasa semakin di dorong untuk mengadopsi suatu kebijakan environmental sustainability, yaitu pengembangan strategi usaha yang dapat memelihara lingkungan hidup secara berkelanjutan dimana pada saat yang sama perusahaan dapat menghasilkan laba. Pada tingkat paling dasar, perusahaan melakukan berbagai aktivitas yang berkaitan dengan pengendalian dan pencegahan polusi.

Pada tahap kedua, perusahaan dapat melakukan aktivitas product stewardship di mana pada kegiatan produksi ini perusahaan tidak hanya meminimalisir terjadinya polusi dari kegiatan produksi, tetapi juga memperkecil dampak yang ditimbulkan dari produk, jadi perusahaan selama masa daur hidup produk tersebut trhadap lingkungan hidup.

Pada tahap ketiga, perusahaan merencanakan untuk menetapakan teknologi-teknologi lingkungan yang baru (new environmental technologies). Misalnya, perusahaan monsanto telah menggeser teknologi pertanian lama yang banyak menggunakan bahan-bahan kimia dengan bioteknologi.

Pada tahap keempat, perusahan dapat mengembangkan suatu sustainability visionyaitu suatu visi yang dapat menjadi pemandu bagi pengembangan produk, proses produksi, teknologi produksi dan berbagai hal lainya yang dapat menjamin tercapainya environ mental sustainability. Kegagalan perusahaan untuk memerhatikan kepentingan para stakeholders sering kali menimbulkan kesulitan yang sangat besar terhadap kelancaran operasional perusahaan.

\section{Konsep Tentang Ekonomi Bisnis}

Menurut Gary Hamel, untuk menjadi revolusioner industri atau dapat membuat aturan permainan baru di era sulit atau era revolusi harus menciptakan konsep bisnis beserta komponen-komponennya. Suatu konsep bisnis di era sulit terdiri dari empat komponen utama, yaitu strategi inti (Core Strategy), sumber 
daya strategis (Strategic Resources), perantara pelanggan (Customer Interface) dan jaringan nilai (Value Network). Empat komponen utama tersebut dikaitkan oleh tiga komponen jembatan. Antara komponen strategi inti dan sumberdaya strategis dikaitkan oleh komponen konfigurasi aktivitas (Configuration of Activities). Komponen manfaat bagi pelanggan (Customer Benefits) mengaitkan strategi inti dan perantara pelanggan. Sedangkan komponen batasan perusahaan (Company Boundaries) menjadi jembatan antara sumberdaya strategis dengan jaringan nilai. Dalam model bisnis di era sulit tersebut mencakup empat elemen penentu potensi profit yang terdiri dari efisiensi, keunikan, kecocokan dan pendorong keuntungan.

Komponen pertama dari konsep bisnis ini adalah strategi inti (Core Strategy), yang merupakan inti dari bagaimana suatu perusahaan memilih cara untuk berkompetisi. Unsur-unsur dari strategi inti tersebut meliputi visi dan misi bisnis, cakupan produk / pasar dan basis diferensiasi. Visi bisnis merupakan apa yang diinginkan perusahaan yang bersifat ideal dan misi bisnis merupakan operasionalisasi dari visi bisnis. Visi dan misi bisnis ini akan mengarah pada pernyataan nilai, kehendak strategi, tujuan dan sasaran yang besar, banyak dan berani serta semua sasaran kinerja. Visi dan misi bisnis ini untuk memberi arah dan seperangkat kriteria untuk mengukur kemajuan yang dicapai. Visi yang dilandasi modal spiritual terbukti dapat melabungkan perusahaan. Merck Pharmaceutical mempunyai visi bahwa perusahaan ini eksis karena menyediakan obat-obatan bagi yang membutuhkannya, sehingga menggerakkan bagian riset untuk bekerja optimal. Komponen pertama ini sangat menentukan keberhasilah sebuah usaha dikarenakan faktor utama usaha.

Komponen kedua dari suatu konsep bisnis di era sulit adalah sumberdaya strategis (Strategic Resources), yang terdiri dari kompetensi inti, aset-aset strategis dan proses inti. Sumberdaya strategis bersifat spesifik dan unik yang dapat mengubah secara dramatis sumberdya kompetisi menjadi sumber inovasi konsep bisnis. Kompetensi ini merupakan sesuatu keunggulan yang dimiliki perusahaan dan mampu memberikan ketrampilan dan kemampuan yang unik. Misalnya Amazon.com, mempunyai sebuah paten teknologi “One-Click" dan mempunyai merek yang sangat kuat merupakan di antara kualitas kompetensi intinya. Tetapi sesungguhnya kompetensi inti dari Amazon.com adalah pengalaman yang diciptakan untuk pelanggannya yaitu nyaman berbisnis dengan Amazon.com. Mengapa nyaman? Karena mudah (One-Click), membuat orang mempersepsikan bahwa mereka berbisnis dan menjual serta membeli produk dengan yang mempunyai merek telah dikenal.

Komponen ketiga perantara pelanggan (Customer Interface) yang mempunyai empat elemen, yaitu dukungan dan pemenuhan, informasi yang mendalam. dinamikan hubungan dan struktur harga. Harley Davidson merupakan perusahaan yang mampu membangun hubungan sejati dengan pelanggannya. 
komponen keempat dari model bisnis adalah jaringan nilai yang mengelilingi perusahaan dan yang memperkuat dan melengkapi sumberdaya yang dimiliki perusahaan. Cisco dan Nokia menggunakan jaringan pemasok mereka sebagai cara untuk mengurangi modal kerja dan meningkatkan fleksibilitas secara dramatis.

\section{Bisnis yang Sesuai dengan Syariah.}

Ada beberapa hal yang perlu diperhatikan dalam jual beli sehingga dapat membawa pada pola transaksi jual beli yang sehat dan menyenangkan. Oleh karena itu, tidaklah cukup mengetahui hukum jual beli tanpa adanya pengetahuan tentang konsep pelaksanaan transaksi jual beli tersebut. Sebenarnya, konsep yang penulis tawarkan tidaklah sulit melainkan konsep yang sering ditemui di kalangan masyarakat. Hanya saja, dalam hal ini, penulis ingin memperkenalkan konsep “JARAS” dalam transaksi jual beli yang mengacu pada Fiqh Islam. Hal ini dimaksudkan agar transaksi tersebut jauh dari perbuatan keji, kotor dan bahkan merugikan.

Banyak para penjual dan pembeli tidak menghiraukan konsep di atas padahal konsep tersebut merupakan awal untuk bangkit dan menguntungkan. Di samping itu, konsep tersebut juga merupakan komponen dalam konsep jual beli dalam fiqh Islam. Jika diperhatikan secara global, memang perilaku tersebut kelihatan remeh, tetapi sebaliknya, jika benar-benar diperhatikan, maka akan dapat membuat pola transaksi jual beli yang sehat, menyenangkan dan bahkan menguntungkan. Konsep tersebut adalah sebagai berikut :

a Jujur

Sifat jujur merupakan sifat Rasulullah saw. yang patut ditiru. Rasulullah saw dalam berbisnis selalu mengedepankan sifat jujur. Beliau selalu menjelaskan kualitas sebenarnya dari barang yang dijual serta tidak pernah berbuat curang bahkan mempermainkan timbangan. Maka, latihlah kejujuran dalam pola transaksi jual beli karena kejujuran dapat membawa keberuntungan. Sebagaimana penjelasan dalam Hadits yang artinya: Dari Abdullah bin Harits. Ia mengadu kepada Hakim bin Hazim ra. Dan beliau berkata bahwa Rasulullah saw bersabda: “penjual dan pembeli dapat melakukan khiyar (memilih) selagi belum berpisah atau sampai keduanya berpisah. Apabila keduanya telah setuju dan jelas maka jual belinya mendapatkan berkah. Dan apabila keduanya saling menekan dan berdusta maka dihapus keberkahan yang ada pada jual belinya (tidak mendapatkan keberkahan)” . (HR. Al-Bukhari)

b Amanah

Amanah dalam bahasa Indonesia adalah dapat dipercaya. Dalam transaksi jual beli, sifat amanah sangatlah diperlukan karena dengan amanah maka semua akan berjalan dengan lancar. Dengan sifat amanah, para penjual dan pembeli akan memiliki sifat tidak saling mencurigai bahkan tidak khawatir walau barangnya di tangan orang. Memulai bisnis biasanya atas dasar kepercayaan. Oleh karena itu, 
amanah adalah komponen penting dalam transaksi jual beli. Sebagaimana dalam Alquran yang artinya: Sesungguhnya Allah menyuruh kamu menyampaikan amanat kepada yang berhak menerimanya, (QS.An-Nisa :58) Artinya: Hai orang-orang yang beriman, janganlah kamu mengkhianati Allah dan Rasul (Muhammad) dan (juga) janganlah kamu mengkhianati amanat-amanat yang dipercayakan kepadamu, sedang kamu mengetahui. (QS. Al-Anfaal : 27)

c Ramah

Banyak orang yang susah untuk berperilaku ramah antar sesama. Sering kali bermuka masam ketika bertemu dengan orang atau bahkan memilah milih untuk berperilaku ramah. Padahal, ramah merupakan sifat terpuji yang dianjurkan oleh agama Islam untuk siapa saja dan kepada siapa saja. Dengan ramah, maka banyak orang yang suka, dengan ramah banyak pula orang yang senang. Karena sifat ramah merupakan bentuk aplikasi dari kerendahan hati seseorang. Murah hati, tidak merasa sombong, mau menghormati dan menyayangi merupakan inti dari sifat ramah. Oleh karena itu, bersikap ramahlah dalam transaksi jual beli karena dapat membuat konsumen senang sehingga betah atau bahkan merasa tentram jika bertransaksi. Sebagaimana keterangan dalam hadits yang artinya : Dari Jabir Bin Abdullah ra. Sesungguhnya Rasulullah saw bersabda: Allah SWT akan mengasihi seseorang yang murah hati ketika menjual, membeli dan meminta. (HR. Al-Bukhari)

d Adil

Adil merupakan sifat Allah swt. Dan Rasulullah saw merupakan contoh sosok manusia yang berlaku adil. Dengan adil, tidak ada yang dirugikan. Bersikap tidak membeda-bedakan kepada semua konsumen merupakan salah satu bentuk aplikasi dari sifat adil. Oleh karena itu, bagi para penjual semestinya bersikap adil dalam transaksi jual beli karena akan berdampak kepada hasil jualannya. Para konsumen akan merasakan kenyamanan karena merasa tidak ada yang dilebihkan dan dikurangkan. Sebagaimana keterangan dalam Alquran yang artinya : *..dan (menyuruh kamu) apabila menetapkan hukum di antara manusia supaya kamu menetapkan dengan adil. Sesungguhnya Allah memberi pengajaran yang sebaik-baiknya kepadamu. Sesungguhnya Allah adalah Maha mendengar lagi Maha melihat. (QS. An-Nisa' : 58)

e Sabar.

Sabar merupakan sikap terakhir ketika sudah berusaha dan bertawakal. Dalam jual beli, sifat sabar sangatlah diperlukan karena dapat membawa keberuntungan. Bagi penjual hendaklah bersabar atas semua sikap pembeli yang selalu menawar dan komplain. Hal ini dilakukan agar si pembeli merasa puas dan senang jika bertransaksi. Begitu pula dengan pembeli, sifat sabar harus ditanamkan jika ingin mendapatkan produk yang memiliki kualitas bagus plus harga murah dan tidak kena tipu. Sebagaimana keterangan dalam Alquran yang artinya : Jika kamu memperoleh kebaikan, niscaya mereka bersedih hati, tetapi jika kamu mendapat 
bencana, mereka bergembira karenanya. jika kamu bersabar dan bertakwa, niscaya tipu daya mereka sedikitpun tidak mendatangkan kemudharatan kepadamu. Sesungguhnya Allah mengetahui segala apa yang mereka kerjakan. (QS. Ali 'Imran : 120).

\section{BAB III \\ PENUTUP}

\section{A. Kesimpulan}

Bisnis merupakan suatu organisasi atau lembaga yang menyediakan barang dan/atau jasa yang bertujuan untuk mendapatkan keuntungan (laba). Dengan demikian, factor pendorong organisasi atau lembaga untuk memulai bisnis dan mengembangkan adalah prospek mendapatkan keuntungan (laba).

Bentuk dasar kepemilikan bisnis secara umum, yaitu : perusahaan perseorangan, persekutuan, perseroan, koperasi. Key result area suatu perusahaan mencakup market standing, innovation, physical and financial resources, profitability, manager performance and development, worker, performance and attitude, public responbility. Komponen pertama dari konsep bisnis ini adalah strategi inti (Core Strategy), Bisnis yang sesuai dengan syariah adalah apabila didalamnya terdapat lima konsep, diantaranya : jujur, amanah, ramah, adil, dan sabar.

B. Saran

Dengan selesainya makalah ini, kami mengucapkan banyak terima kasih kepada semua pihak yang ikut andil wawasannya dalam penulisan ini. Tak lupa kami menyadari bahwa dalam penulisan makalah ini masih jauh dari kesempurnaan, untuk itu saran dan kritik yang membangun selalu kami tunggu dan kami perhatikan. Semoga Allah SWT membalas semua jerih payah semua pihak yang telah membantu dengan senang hati untuk menyelesaikan makalah ini dan semoga bermanfaat bagi kita semua, Amin yarabbal alamin. 


\section{REFERENCES}

[1] Yapanto, L.M., Musa, F.T. （2018). Distribution of

Seafood Production in Bajo Sector of Gorontalo Province Indonesia. International Journal of Innovative Science and Research Technology, 3(8). www.ijisrt.com521

[2] Yapanto, L. M., \& Olilingo, F. Z. (2020). The contribution of the fisheries and marine sectors to improving regional income. 22(10), 1307-1321.

[3] Muhaimin, A. W., Toiba, H., Retnoningsih, D., \& Yapanto, L. M. (2020). The Impact of Technology Adoption on Income and Food Security Of Smallholder Cassava Farmers: Empirical Evidence From Indonesia. 29(9), 699-706

[4] Setiawan, R., Pio, L., Cavaliere, L., Sankaran, D., Rani, K., Yapanto, L. M., Laskar, N. H., Raisal, I., Christabel, G. J. A., Setiawan, R., Petra, U. K., Airlangga, U., Pio, L., Cavaliere, L., \& Foggia, U. (n.d.). Access to Financial Services and Women Empowerment, through Microfinance eligibility. 1, 841-859. 
[5] Yapanto, L. M., Tanipu, F., Paramata, A. R., \& Actors, E. (2020). THE EFFECTIVENESS OF FISHERY COOPERATIVE INSTITUTIONS. 17(25), 1329-1338.

[6] Muhaimin, A. W., \& Wijayanti, V. (2019). ANALYSIS OF MARKET STRUCTURE, CONDUCT AND PERFORMANCE OF CORN (ZEA MAYS L.) IN KEDUNG MALANG VILLAGE, PAPAR DISTRICT, KEDIRI REGENCY, EAST JAVA. International Journal of Civil Engineering and Technology (IJCIET), 10, 10-16.

http://www.iaeme.com/ijciet/issues.asp?JType=IJCIET\& VType $=10 \&$ IType $=06$

[7] Yapanto, L. (2019). Marketing Efficiency of Sea Food Production in Bajo District Boalemo Province Gorontalo. 1985. https://zenodo.org/record/2578439

[13] Muhaimin, A. W., Toiba, H., Retnoningsih, D., \& Yapanto, L. M. (2020). The Impact of Technology Adoption on Income and Food Security Of Smallholder Cassava Farmers: Empirical Evidence From Indonesia. 29(9), 699-706. 
[8] Yapanto, L.M. (2019). Marketing Efficiency of Sea Food Production in Bajo District Boalemo Province Gorontalo. 1985.

\section{https://zenodo.org/record/2578439}

[9] Yapanto, L. M., \& Nursinar, S. (n.d.). Traditional

Handline Fishing in Pohuwato Regency, Indonesia. 6, $24-30$.

[10] Sundram, S., Venkateswaran, P. S., Jain, V., Yu, Y., Yapanto, L. M., Raisal, I., Gupta, A., \& Regin, R. (2020). The Impact of Knowledge Management on The Performance of Employees: The Case of Small Medium Enterprises. Productivity Management, 25(1S), 554-567.

[11] Yapanto, M.L., \& Modjo, M. L. (2018). Assessing public awareness level on the preservation of coral reefs (The case study in Biak Numfor, Papua, Indonesia). In Copyright@ EM International.

[12] Baruadi, A. S. R., \& Yapanto, L. M. (2020). Supporting the capacity of coastal areas in North Gorontalo District. 8(11), 1932-1941. 
